\title{
Study on System Frame of China Industry Boilers Energy Efficiency Standards
}

\author{
Ren LIU ${ }^{\mathrm{a}, \mathrm{b}}$, Yuejin ZHAO ${ }^{\mathrm{a}}$, Lili Chen ${ }^{\mathrm{a}}$, Haihong Chen $^{\mathrm{a}}$ \\ ${ }^{a}$ China National Institution of Standardization, Beijing, 100191, China \\ ${ }^{b}$ Department of thermal engineering, Tsinghua University, Beijing, 100084, China
}

\begin{abstract}
Energy consumption is always concerned by China government, from 11th five years plan, central government and departments are trying to deduce the energy consumption and $\mathrm{CO} 2$ emission. Massive energy were consumed by industry boiler that pointed out by investigation of energy in China industry, standards for boilers, specially energy efficiency standards are always considered to be a key approach to reduce energy consumption and promote high energy efficiency technology. From the results of survey, industry boiler energy efficiency standards are indeed useful to reduce energy consume. In this paper, we try to research on China industry boilers energy efficiency standards, based on that we concluded the system of China industry boiler energy efficiency standards, and listed all the index of those energy efficiency standards which force to comply. It is very useful to make everyone to understand China industry boiler, and industry boiler energy efficiency standards.
\end{abstract}

\section{Introduction}

Boiler is an important energy conversion device, as it can be used to provide stream for industrial use, generate electricity, and provide heat or hot water for civil use, and etc[1]. based on date of China industry boilers survey, we know that at the end of 2015, there were 579, 000 boilers nationwide according to "AQSIQ Report on the state of national special equipment safety condition in 2015", and most of them industrial boilers.

In China, industry boilers are widely used, so there have huge total amount industry boiler. those equipment are all high consumption and heavy pollution, since the Chinese government revised the energy conservation law in 2007[2,3], boiler and other high energy consuming special equipment energy conservation supervision was more and more concerned, and in 2014 the Chinese government has enacted the new revision "atmospheric pollution prevention and control law" in which boiler emissions management requirement was increased. But because of boiler energy conservation and environmental protection work started late in China, relevant working basis is weak and the indicators for boiler efficiency, emissions are not perfect, to a certain extent, it restricted the progress of boiler energy conservation and environmental protection work in China.

This paper researched China compulsory industry boiler energy efficiency standards. For easy understanding, we studied on the administrative agency which promulgate regulation, standards and related organizations before that. In the last, we listed all index which force to comply with by user and manufacture of industry boiler.

\section{Administrative Agency Of Chinese Regulations And Standards}

According to Chinese regulations and standards system, the structural level is usually "law - administrative regulations-department rules - safety technology specifications - related standards" from top to bottom.

Laws: Chinese legislation includes the legislation of the National People's Congress and its standing committee, legislation of State Council and its departments, common local legislation, local legislation of national autonomy[4], legislation of special economic zones and special administrative regions. The laws concerning boilers, including Energy conservation Law, Safety Law on Special Equipment and Air Pollution Prevention and Control Law have confirmed the basis for regulation of energy conservation of energy intensive special equipment.

Administrative regulations: the formulating body of the administrative regulations is the State Council; its force is only second to laws, and is higher than the department rules and local regulations. The Safety Supervision Rules on Special Equipment is related to boilers; and the Safety Supervision Rules on Special Equipment revised in 2009 has brought up requirements for energy conservation work of the boiler.

Department rules: the department rules are the normative documents formulated and issued by departments of State Council in their authority scope for adjusting the administrative relations in this department and shall not conflict with the Constitution, laws and administrative regulations[5]. It mainly takes the form of 
orders, instructions and regulations etc. For example, the Procedures of Energy Conservation Supervision of Energy Intensive Special Equipment; the Administrative Measures on Energy Conservation and Environment Protection Supervision of Boilers jointly formulated by AQSIQ, Ministry of Environmental Protection and NDRC are all department rules.

Safety technology specifications: the safety technology specifications on special equipment are formulated by AQSIQ, the administrative agency of special equipment, mainly including the basic compulsory safety requirements for safety performance, energy efficiency indicator, production, operation, use and inspection rules of special equipment, e.g. Supervision and Administration Specifications on Energy Conservation Technology of Boilers.[6,7]

Standard: according to provisions on Law of Standardization, the standards in China can be classified into four types. National standards, industrial standards, local standards and enterprise standards [8].

National standards: for the nation-wide unified technological requirements, it is required to formulate national standards. Based on different contents, the national standards can be classified into compulsory standards and recommendatory standards. The administrative department of standardization of State Council, National Standardization Administration Committee, formulates the plan and organizes the drafting work of national standards, approves, numbers and publishes the standards. Current standards such as Minimum Allowable Values of Energy Efficiency and Energy Efficiency Grades of Industrial Boilers (GB 24500-2009), Thermal Performance Test Code for Industrial Boilers (GB/T 10180-2003) and Emission Standard of Air Pollutants for Boilers (GB 13271-2014) are all national standards.

Industrial standards: for the technological requirements without national standards but needing to be unified in a certain industry of the country, the industrial standards can be formulated as the supplement of national standards [9]; after the implementation of corresponding national standards, the industrial standards will be abolished automatically[10,11]. For example, the energy efficiency test standard of circulating fluidized bed boiler, Performance Test Specifications on Circulating Fluidized Bed Boilers (DL/T 964-2005).

Local standards: for the following requirements without national standards or industrial standards but needing to be unified in the scope of province, autonomous region or municipality directly under central government, local standards can be formulated.

Enterprise standards: the enterprise standards are the standards formulated for the technological requirements, administrative requirements and work requirements

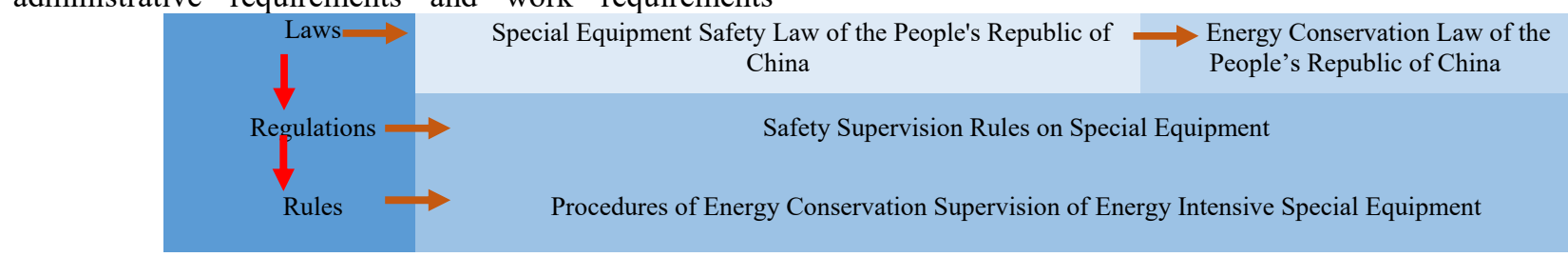

Fig1. Framework of Regulations and Standards System on Energy Conservation of Industrial Boilers which shall be coordinated and unified in the scope of enterprises. The enterprise standards are formulated by enterprises and shall be approved and issued by corporate representative or the person in charge authorized by legal representative.

\section{SYSTEM OF ENERGY CONSERVATION STANDARDS ON BOILERS IN CHINA}

Since the Energy Conservation Law revised in 2007 and the Safety Supervision Rules on Special Equipment revised in 2009 have added the contents on energy conservation supervision of energy intensive special equipment, in 2009, AQSIQ had issued the Procedures of Energy Conservation Supervision of Energy Intensive Special Equipment (Decree No.116), identified the mechanism and contents of emergency conservation supervision of energy intensive special equipment and proposed the specific requirements for energy conservation work during the production and use of energy intensive special equipment; in 2010, it had issued two energy conservation technology specifications, namely the Supervision and Administration Specifications on Energy Conservation Technology of Boilers and the Energy Efficiency Test and Evaluation Regulation for Industrial Boilers, which have specified the energy efficiency test, test method, energy efficiency indicator and so forth of the industrial boilers; in 2011, it has issued the Energy Conservation Inspection Methods of Boiler Design Documents (Trial) to propose a series of specific requirements for the energy conservation inspection of boiler design documents, energy efficiency test of approved boiler products, regular energy efficiency test of boiler and the operation management of boilers. In the meanwhile, related standardization technology committees have formulated and revised more than 20 related standards such as Construction Specifications of Volute Boilers and Construction Specifications of Tubular Boilers to specify the energy and material conservation requirements, thus confirming the framework of energy conservation regulations and standards system on energy-intensive special equipment with Energy Conservation Law and Safety Supervision Rules on Special Equipment as the law basis, Procedures of Energy Conservation Supervision of Energy Intensive Special Equipment as the work requirements and Supervision and Administration Specifications on Energy Conservation Technology of Boilers and other energy conservation technology specifications and related standards as the basis of work $[12,13]$; see details in Fig1. 


\section{Energy Efficiency Indicator Of Industrial Boiler}

Chinese standards in energy performance of industrial boiler mainly include General Specification for Industrial Boilers (JB/T10094-2002), Thermal Efficiency and Test Methods of Boilers for Daily Life (GB/T 10820- 2011), Minimum Allowable Values of Energy Efficiency and Energy Efficiency Grades of Industrial Boilers

Table 1. Energy Efficiency Indicators for Some Coal-fired Boilers in the General Specification for Industrial Boilers

\begin{tabular}{|c|c|c|c|c|c|c|c|}
\hline \multirow{3}{*}{\multicolumn{2}{|c|}{ Variety of fuels }} & \multirow{3}{*}{ Low heat value of fuel as received basis } & \multicolumn{5}{|c|}{$\begin{array}{l}\text { Boiler capacity D } \\
\text { t/h or MW }\end{array}$} \\
\hline & & & \multicolumn{2}{|c|}{\begin{tabular}{|l|l|l|}
$\mathrm{D}<1$ or & $1 \leq \mathrm{D} \leq 2$ \\
$\mathrm{D}<0.7$ & $0.7 \leq \mathrm{D} \leq 1.4$ \\
\end{tabular}} & or $2<\mathrm{D} \leq 8$ or $1.4<\mathrm{D} \leq 5.6$ & $8<\mathrm{D} \leq 20$ or $5.6<\mathrm{D} \leq \mathrm{I} 4$ & \multirow[t]{2}{*}{$\mathrm{D}>20$ or $\mathrm{D}>14$} \\
\hline & & & \multicolumn{4}{|c|}{ Boiler thermal efficiency \% } & \\
\hline \multirow{2}{*}{ Soft coal } & II & $17700 \leq Q_{n e t, v, a r} \leq 21000$ & 71 & 74 & 76 & 77 & 78 \\
\hline & III & $Q_{n e t, v, a r}>21000$ & 73 & 76 & 78 & 79 & 80 \\
\hline \multicolumn{2}{|c|}{ Meager coal } & $Q_{\text {net, }, \text { ar }} \geq 17700$ & 69 & 72 & 74 & 76 & 77 \\
\hline \multirow{2}{*}{$\begin{array}{l}\text { Smokeless } \\
\text { coal }\end{array}$} & II & $Q_{n e t, v, a r} \geq 21000$ & 58 & 61 & 64 & 66 & 69 \\
\hline & III & $Q_{n e t, v, a r} \geq 21000$ & 63 & 68 & 72 & 74 & 77 \\
\hline \multicolumn{2}{|c|}{ Brown coal } & $Q_{n e t, v, a r} \geq 11500$ & 69 & 72 & 74 & 76 & 78 \\
\hline \multicolumn{8}{|c|}{$\begin{array}{l}\text { Note 1: the thermal efficiency of coal-fired manual boiler (less than } 1 \mathrm{t} / \mathrm{h} \text { or less than } 0.7 \mathrm{MW} \text { ) is permitted to be } 3 \% \text { lower than the specifiec } \\
\text { value in the table. }\end{array}$} \\
\hline
\end{tabular}

Table 2. Energy Efficiency Indicators of Oil and Gas in the General Specification for Industrial Boilers

\begin{tabular}{|c|c|c|c|c|c|}
\hline \multirow{4}{*}{ Variety of fuels } & \multicolumn{5}{|c|}{$\begin{array}{l}\text { Boiler capacity D } \\
\text { t/h or MW }\end{array}$} \\
\hline & \multirow[t]{3}{*}{$\begin{array}{l}\text { Low heat value of fuel } \\
\text { received basis } \mathrm{kJ} / \mathrm{kg}\end{array}$} & \multicolumn{2}{|c|}{$\begin{array}{l}\text { as } \begin{array}{l}\text { Steam boiler } \\
\text { economizer }\end{array}\end{array}$} & \multicolumn{2}{|c|}{$\begin{array}{l}\text { without Hot water boiler and steam boiler with } \\
\text { economizer }\end{array}$} \\
\hline & & $\mathrm{D} \leq 2$ & $D>2$ & $\mathrm{D} \leq 2$ or $\mathrm{D} \leq 1.4$ & $\mathrm{D}>2$ or $\mathrm{D}>1.4$ \\
\hline & & \multicolumn{4}{|c|}{ Boiler thermal efficiency \% } \\
\hline Heavy oil & - & 84 & 86 & \begin{tabular}{l|l}
86 \\
\end{tabular} & 88 \\
\hline Light oil & - & 86 & 88 & 88 & 90 \\
\hline Gas & $\square$ & 86 & 88 & 88 & 90 \\
\hline
\end{tabular}

Table 3. Energy Efficiency Indicators of Coal-fired Boiler in the Thermal Efficiency and Test Methods of Boilers for Daily Life

\begin{tabular}{|c|c|c|c|c|c|c|c|}
\hline \multirow{3}{*}{$\begin{array}{l}\text { Boiler rating } \\
\mathrm{D} /(\mathrm{t} / \mathrm{h}) \\
\text { Or rated thermal power of } \\
\text { boiler N/MW }\end{array}$} & \multirow{2}{*}{ Brown coal } & \multicolumn{3}{|c|}{ Soft coal } & \multirow{2}{*}{ coal } & \multicolumn{2}{|c|}{ Smokeless coal } \\
\hline & & I & II & III & & II & III \\
\hline & \multicolumn{7}{|c|}{ Boiler thermal efficiency } \\
\hline $\begin{array}{l}\mathrm{D} \leq 0.143 \\
\mathrm{~N} \leq 0.1\end{array}$ & 65 & 62 & 65 & 68 & 65 & \multirow{2}{*}{58} & \multirow{2}{*}{63} \\
\hline $\begin{array}{l}0.143<\mathrm{D}<0.50 \\
0.1<\mathrm{KN}<0.35\end{array}$ & 67 & 65 & 68 & 72 & 69 & & \\
\hline $\begin{array}{l}0.5 \leq \mathrm{D}<1 \\
0.35 \leq \mathrm{N}<0.7\end{array}$ & 71 & 68 & 72 & 74 & 71 & 60 & 65 \\
\hline
\end{tabular}




\begin{tabular}{|l|l|l|l|l|l|l|l|}
\hline $0.7 \leq \mathrm{N} \leq 1.4$ & 73 & 70 & 74 & 76 & 73 & 63 & 70 \\
\hline $\mathrm{N}>1.4$ & 75 & 72 & 76 & 78 & 75 & 66 & 74 \\
\hline
\end{tabular}

Table 4. Energy Efficiency Indicators of Oil and Gas Fired Boilers in the Thermal Efficiency and Test Methods of Boilers for Daily Life

\begin{tabular}{|c|c|c|c|}
\hline $\begin{array}{l}\text { Boiler rating } \mathrm{D} /(\mathrm{t} / \mathrm{h}) \text { or rated } \\
\text { thermal power } \mathrm{N} / \mathrm{MW}\end{array}$ & Oil $^{\text {a }}$ & Gas $^{b}$ & Electric heating \\
\hline $\begin{array}{l}\mathrm{D}<1 \\
\mathrm{~N}<0.7\end{array}$ & 86 & 86 & \multirow{3}{*}{97} \\
\hline D. $7 \leq \mathrm{N} \leq 1.4$ & 88 & 88 & \\
\hline $\mathrm{N}>1.4$ & 90 & 90 & \\
\hline
\end{tabular}

The Minimum Allowable Values of Energy Efficiency and Energy Efficiency Grades of Industrial Boilers (GB24500-2009) specifies energy efficiency grades of industrial boilers and the maximum advantage of the standard is that it specifies and classifies the limit and target values for thermal efficiency of boilers. Under the test conditions specified in the standard, the permitted minimum thermal efficiency of industrial boiler under rated working conditions e.g. thermal efficiency of coal-fired industrial boiler under the rated working conditions, should not be lower than the energy efficiency "Grade 3" in Fig. 5.6. In the Supervision Regulation on Saving Energy Technology for Boiler, the limit and target values of boiler thermal efficiencies are corresponding as well. The limit of thermal efficiency corresponds to Grade 3 of GB 24500 and the target value to Grade 1 of GB 24500, GB 24500-2009.

Table 5 Energy efficiency indicators of layer combustion boilers in the Minimum Allowable Values of Energy Efficiency and Energy Efficiency Grades of Industrial Boilers

\begin{tabular}{|c|c|c|c|c|c|c|c|c|}
\hline \multirow{3}{*}{$\begin{array}{l}\text { Energy } \\
\text { efficiency } \\
\text { grade }\end{array}$} & \multirow{3}{*}{\multicolumn{2}{|c|}{$\begin{array}{l}\text { Variety of } \\
\text { fuels }\end{array}$}} & \multirow{3}{*}{ Low heat value of fuel as received basis } & \multicolumn{5}{|c|}{$\begin{array}{c}\text { Boiler capacity } \\
D \\
\mathrm{t} / \mathrm{h}(\text { or } \mathrm{MW})\end{array}$} \\
\hline & & & & $\mathrm{D}<1($ or $\mathrm{D}<0.7)$ & $\begin{array}{l}1 \leq \mathrm{D} \leq 2(\text { or } \\
0.7 \leq \mathrm{D} \leq 1.4)\end{array}$ & $\begin{array}{l}2<\mathrm{D} \leq 8 \text { ( or } \\
1.4<\mathrm{D} \leq 5.6)\end{array}$ & $\begin{array}{c}8<\mathrm{D} \leq 20 \text { ( or } \\
5.6<\mathrm{D} \leq 14\end{array}$ & $\mathrm{D}>20($ or $\mathrm{D}>14)$ \\
\hline & & & & \multicolumn{5}{|c|}{ Boiler thermal efficiency $\%$} \\
\hline \multirow{2}{*}{ Grade 1} & \multirow{6}{*}{$\begin{array}{l}\text { Gas } \\
\text { coal }\end{array}$} & II & $17700 \leq Q_{\text {net, }, a r} \leq 21000$ & 79 & 82 & 84 & 85 & 86 \\
\hline & & III & $Q_{n e t, v, a r}>21000$ & 81 & 84 & 86 & 87 & 88 \\
\hline \multirow{2}{*}{ Grade 2} & & II & $17700 \leq Q_{n e t, v, a r} \leq 21000$ & 76 & 79 & 81 & 82 & 83 \\
\hline & & III & $Q_{n e t, v, a r}>21000$ & 78 & 81 & 83 & 84 & 85 \\
\hline \multirow{2}{*}{ Grade 3} & & II & $17700 \leq Q_{n e t, v, a r} \leq 21000$ & 73 & 76 & 78 & 79 & 80 \\
\hline & & III & $Q_{n e t, v, a r}>21000$ & 75 & 78 & 80 & 81 & 82 \\
\hline Grade 1 & \multirow{3}{*}{\multicolumn{2}{|c|}{ Meager coal }} & $Q_{n e t, v, a r} \geq 17700$ & 77 & 80 & 82 & 84 & 85 \\
\hline Grade 2 & & & $Q_{n e t, v, a r} \geq 17700$ & 74 & 77 & 79 & 81 & 82 \\
\hline Grade 3 & & & $Q_{n e t, v, a r} \geq 17700$ & 71 & 74 & 76 & 78 & 79 \\
\hline
\end{tabular}

However, the Minimum Allowable Values of Energy Efficiency and Energy Efficiency Grades of Industrial Boilers has a lot of problems, for example, the specified energy-saving assessment value is too low, the thermal efficiency of the oil-gas boiler is especially lower, and the standard still uses the efficiency as the sole energy efficiency indicator. Though the target value of efficiency is slightly higher than that specified in the previous standards, other indicators affecting boiler energy efficiency are not specified, which is adverse to further improvement of the design and manufacturing level of industrial boilers.

\subsection{Test And Assessment Methods}

At present, the valid test and assessment methods in China mainly include the Thermal Performance Test Code for Industrial Boiler (GB/T 10180-2003); the Performance Test Code for Utility Boiler (GB/T 10184-2015); the Performance Test Code for Circulating 
Fluidized Bed Boiler (DL/T 964-2005); the Energy Efficiency Test and Evaluation Regulation for Industrial Boiler)(TSGG0003-2010); the Energy Performance Assessment for Industrial Boilers System (NB/T47035-2013), etc.

\subsubsection{Test method}

At present, as for the energy efficiency test of industrial boiler, the test methods in the Thermal Performance Test Code for Industrial Boiler (GB/T 10180-2003) and the Energy Efficiency Test and Evaluation Regulation for Industrial Boiler) (TSGG0003-2010) are mainly quoted from the provisions of the Thermal Performance Test Code for Industrial Boiler in our country, and the difference is the provisions for types of boiler energy efficiency tests.

\subsubsection{Assessment method}

As the test and assessment work of boiler energy efficiency is just commenced at home, the current assessment standard is only the Energy Performance Assessment for Industrial Boilers System (NB/T47035-2013), of which the application range includes: energy efficiency assessment of steam boiler system with rated steam pressure $\leq 3.8 \mathrm{MPa}$; hot water

Table 6. Emission Concentration Limit of Atmospheric Pollutants of Boilers in use

\begin{tabular}{|c|c|c|c|c|}
\hline \multicolumn{5}{|l|}{ Unit: $\mathrm{mg} / \mathrm{m} 3$} \\
\hline \multirow[b]{2}{*}{ Pollutant items } & \multicolumn{3}{|l|}{ Limits } & \multirow{2}{*}{$\begin{array}{c}\text { Pollutant emission } \\
\text { monitoring positions }\end{array}$} \\
\hline & \begin{tabular}{|l} 
Coal-fired \\
boiler
\end{tabular} & Oil-fired boiler & Gas-fired boiler & \\
\hline Particles & 80 & 60 & 30 & \multirow{4}{*}{ Chimney or flue } \\
\hline Sulfur dioxide & $\begin{array}{l}400 \\
550(1)\end{array}$ & 300 & 100 & \\
\hline NOx & 400 & 400 & 400 & \\
\hline Mercury and other compounds & 0.05 & - & - & \\
\hline Fume blackness (Ringelman blackness, level) & \multicolumn{3}{|l|}{$\leq 1$} & $\begin{array}{ll}\text { Sort } & \text { Smoke } \\
\text { pomission }\end{array}$ \\
\hline
\end{tabular}

Table 7. Limit of Atmospheric Pollutant Emission Concentration for New Boilers

\begin{tabular}{|c|c|c|c|c|}
\hline \multicolumn{5}{|l|}{ Unit: $\mathrm{mg} / \mathrm{m} 3$} \\
\hline \multirow[b]{2}{*}{ Pollutant items } & \multicolumn{3}{|l|}{ Limits } & \multirow{2}{*}{$\begin{array}{l}\text { Pollutant emission } \\
\text { monitoring positions }\end{array}$} \\
\hline & $\begin{array}{l}\text { Coal-fired } \\
\text { boiler }\end{array}$ & Oil-fired boiler & Gas-fired boiler & \\
\hline Particles & 50 & 30 & 20 & \multirow{4}{*}{ Chimney or flue } \\
\hline Sulfur dioxide & 300 & 200 & 50 & \\
\hline NOx & 300 & 250 & 200 & \\
\hline Mercury and other compounds & 0.05 & - & - & \\
\hline Fume blackness (Ringelman blackness, level) & \multicolumn{3}{|l|}{$\leq 1$} & port \\
\hline
\end{tabular}

boiler system; organic heat carrier boiler system and so on, but the energy efficiency assessment of exhaust heat boiler and combined heat and power boiler systems can be done with reference to this standard and the assessment method is substantially similar to American ASME EA-1 Standard, mainly by collecting and analyzing integral design, operation, energy utilization, operating data and other information of the system to identify the chance for improvement of the system's energy efficiency and propose the schemes for optimize energy utilization and performance of the system so as to achieve energy-saving and emission-reducing effects.

At present, Chinese current environmental protection standard for industrial boiler is the Emission Standard of Air Pollutants for Boiler, which is jointly issued by the Ministry of Environmental Protection and the General Administration of Quality Supervision, Inspection and Quarantine of the People's Republic of China and specifies the limit emission indicators for in-use boilers, new boilers and special areas as shown in table $6 \sim$ table 8 .

\subsection{Conditions Of Environmental Protection Standards For Industrial Boiler In China}


Table 8. Special Limit of Atmospheric Pollutant Emission

\begin{tabular}{|c|c|c|c|c|}
\hline \multicolumn{5}{|l|}{ Unit: $\mathrm{mg} / \mathrm{m}^{3}$} \\
\hline \multirow{2}{*}{ Pollutant items } & \multicolumn{3}{|l|}{ Limits } & \multirow{2}{*}{$\begin{array}{l}\text { Pollutant emission } \\
\text { monitoring } \\
\text { positions }\end{array}$} \\
\hline & Coal-fired boiler & Oil-fired boiler & Gas-fired boiler & \\
\hline Particles & 30 & 30 & 20 & \multirow{4}{*}{ Chimney or flue } \\
\hline Sulfur dioxide & 200 & 100 & 50 & \\
\hline NOx & 200 & 200 & 150 & \\
\hline Mercury and other compounds & 0.05 & - & - & \\
\hline Fume blackness (Ringelman blackness, level) & $\leq 1$ & & & $\begin{array}{ll}\text { Smoke } & \text { emission } \\
\text { port } & \\
\end{array}$ \\
\hline
\end{tabular}

At present, the standard is the latest standard in the field of boilers' atmospheric pollutant emission in China. As local governments increasingly pay attention to environmental protection, stricter local standards have been issued according to this standard in Beijing-Tianjin-Hebei Region, Shandong, Guangdong and other regions with concentrated petroleum and petrochemical enterprises.

\section{Conclusion}

We concluded China industry boilers energy efficiency standards, before that, we first combs relatively theoretic frame and related government departments, organizations, then bring up laws, regulations one by one, list administrative agency of standards in each level from national to local. By study on those standards and frame of standards, the purpose is to put forward perfecting suggestion for China industrial boiler energy efficiency index system, and expect to provide relevant reference basis for national relevant departments when formulating industrial boiler energy conservation planning, related policies, standards, or popularize advanced energy conservation technology and strengthening energy conservation management which allowing the government to formulate more reasonable policies and measures to promote the improvement of the economic operation level of the boiler in the region and industry.

\section{References}

1. Yang Jisheng, Relative Energy Price at Home and Abroad and Energy Efficiency of China [J], Economist, 2009, (4): 90-97.

2. Dong Zhenbin, Liu Jingqi. Energy Conserving Status and Prospect of Industrial Motor System in China [J]. Power Demand Side Management, 2016, (2): $1-4$

3. Ma Wei. Subsidy of MIIT for Energy Conserving Transformation of Motor System [J]. Textile
Machinery. 2014(9): 26-26

4. Pan Jianjun, Chen Xiang, Song Jianxiong, Li Jue. Application of Energy Conserving Technology of Motor System in Enterprises [J]. Telecom Power Technology. 2016(05): 75.

5. Sun Bailin. Energy Efficiency of Motor System: Development Trend of Energy Conserving Technology of Motor System [J]. Electric Time. 2014 (2): 26-29

6. Han Qingyuan. Application of Energy Conserving Technology of Motor System in Enterprises [J]. Private Science and Technology. 2014(09): 75

7. Qin Hongbo. Overview on Energy Efficiency Status of Motor System and Analysis Method of Energy Conserving Potential $[\mathrm{J}]$. Shanghai Energy Conserving. 2009(02): 4-7

8. Compiled by the energy conserving project team of motor system in China. Analysis on Energy Efficiency and Market Potential of Motor System in China [M]. China Machine Press, 2001

9. Qin Hongbo. Energy Conserving Progress and Countermeasure of Motor System in China [J]. Motor \& Control Application. 2010 (06): 1-4

10. Chen Weihua, Li Xiuying, Yao Peng. Overview on the Development of Energy Conserving Technology of Motor and its System [J]. Motor \& Control Application. 2008, 35(9): 1-5

11. Li Zhengxi. Key Technology and Prospect for Energy Conserving of Motor System [J]. Nonferrous Metals Engineering \& Research. 2015, 36 (3): 1-5

12. Zhang Xiaoping, Sun Lei. Decomposition Analysis on Intensity Change of Industrial Energy Consumption in China [J]. Resource Science, 2010, 32 (9): 1685-1691

13. Zhao Zhengming, Li Chongjian. One of the Top Ten Key Energy Conserving Projects in the "11th Five-year Plan" - Energy Conserving of Motor System [J]. Electric Time. 2006 (10): 16-18 